Jurnal Ilmu Sosial dan Pendidikan (JISIP)

Vol. 6, No. 1 Januari 2022

e-ISSN : 2656-6753, p-ISSN: 2598-9944

DOI: 10.36312/ jisip.v6i1.2744/http://ejournal.mandalanursa.org/index.php/JISIP/index

\title{
Kinerja Layanan Sekretariat Dewan Perwakilan Rakyat Daerah (DPRD) Kabupaten Bulukumba
}

\author{
${ }^{1}$ Nursafitra M, ${ }^{2}$ Andi Agustang, ${ }^{3}$ Andi Muhammad Idkhan, ${ }^{4}$ Aswar Annas \\ ${ }^{1,2,3}$ Universitas Negeri Makassar \\ ${ }^{4}$ Universitas Pepabri Makassar
}

\begin{abstract}
Article Info
Article history:

Received 22 Desember 2021

Publish 04 Januari 2022

\begin{tabular}{l}
\hline Keywords: \\
Kinerja, \\
Layanan, \\
Sekretariat \\
Dewan \\
Perwakilan \\
Rakyat Daerah \\
$($ DPRD)
\end{tabular}

Abstract

This study aims to measure the of the services of the Bulukumba DPRD. The secretariat consist of a general and financial section, a court and legislation section, and a budgeting and monitoring facility section. This study uses a quantitative method with a non-probability sampling technique, the measurement with a Likert scale consists of 30 respondents, namely members of the Bulukumba Regency DPRD for the 2019-2024 period, the determination of the sample is carried out by purposive sampling. The results showed that the performance of the secretariat services of the Bulukumba Regency DPRD was 73.62 with poor quality. Meanwhile, the performance of general and financial services is 73.13 with poor service quality. The service performance of the court and legislation section is 74.35 with poor service quality. And the service performance of the budgeting and monitoring facilities section is 73.37 with poor service quality as well.
\end{abstract}

Article Info

Article history:

Received 22 Desember 2021

Publish 04 Januari 2022

\begin{abstract}
Penelitian ini bertujuan untuk mengukur kinerja layanan sekertariat DPRD Kabupaten Bulukumba. Layanan sekertariat tersebut terdiri dari bagian umum dan keuangan, bagian persidangan dan perundang-undangan, dan bagian fasilitas penganggaran dan pengawasan. Penelitian ini menggunakan metode kuantitatif dengan teknik non-probability sampling, pengukuran dengan skala likert terdiri dari 30 responden yaitu anggota DPRD Kabupaten Bulukumba periode 20192024, penentuan sampel dilakukan secara purposive sampling. Hasil penelitian menunjukkan bahwa kinerja layanan sekertariat DPRD Kabupaten Bulukumba yaitu 73,62 dengan mutu kurang baik. Sedangkan kinerja layanan bagian umum dan keuangan yaitu 73,13 dengan mutu layanan kurang baik. Kinerja layanan bagian persidangan dan perundang undangan yaitu 74,35 dengan mutu layanan kurang baik. Dan kinerja layanan bagian fasilitas penganggaran dan pengawasan yaitu 73,37 dengan mutu layanan kurang baik pula
\end{abstract}

This is an open access article under the Lisensi Creative Commons AtribusiBerbagiSerupa 4.0 Internasional

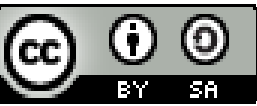

Corresponding Author:

Nursafitra $M$

Universitas Negeri Makassar

Email: vitanursafitra@gmail.com

\section{PENDAHULUAN}

Dewan Perwakilan Rakyat Daerah (DPRD) Kabupaten/Kota merupakan lembaga perwakilan rakyat yang memiliki kedudukan sebagai lembaga unsur pelayanan dan aspirasi masyarakat dalam pelaksana penyelenggara pemerintah daerah Kabupaten/Kota, sebagaimana bunyi pasal 364 pada Undang-Undang nomor 17 Tahun 2014 Tentang MPR, DPR, DPD, dan DPRD. Dewan Perwakilan Rakyat Daerah (DPRD) dalam menjalankan fungsi dan tugasnya 
didukung oleh sekretariat DPRD. Berdasarkan pasal 204 Undang-Undang nomor 23 Tahun 2014 Tentang pemerintah daerah pasal 209 dan 215, diperjelas oleh Peraturan Bupati nomor 62 Tahun 2018, bahwa sekertariat Dewan Perwakilan Rakyat Daerah (DPRD) memiliki tugas sebagai penyelenggara administrasi kesektariatan dan keuangan, mendukung pelaksana tugas dan fungsi DPRD, serta menyediakan dan mengoordinasikan tenaga ahli, SKPD yang diperlukan oleh DPRD dalam melaksanakan fungsinya sesuai dengan kebutuhan masyarakat.

Sekretariat Dewan Perwakilan Rakyat Daerah (DPRD) sebagaimana pasal 204 Undang Undang nomor 17 Tahun 2014 tentang pemerintah daerah dan pasal 5 ayat 2 peraturan pemerintah nomor 18 Tahun 2016 tentang organisasi perangkat daerah merupakan salah satu perangkat daerah yang dibentuk untuk mendukung kelancaran pelaksanaan tugas dan wewenang DPRD Kabupaten/Kota. Sekretariat DPRD sebagai unsur pelayan administrasi dan pemberian dukungan serta kelengkapan terhadap implementasi tugas dan fungsi DPRD Kabupate/Kota. Kemudian Undang-Undang tersebut menjadi dasar dalam perumusan dan penetapan Peraturan Daerah Kabupaten Bulukumba nomor 6 Tahun 2014 tentang organisasi dan tata kerja sekretariat daerah dan sekretariat dewan perwakilan rakyat daerah Kabupaten Bulukumba. Selanjutnya peraturan daerah tersebut dijabarkan dalam peraturan bupati Bulukumba nomor 62 Tahun 2018 tentang kedudukan, susunan organisasi, tugas dan fungsi serta tata kerja sekretariat DPRD Kabupaten Bulukumba.

Sekretariat Dewan Perwakilan Rakyat Daerah (DPRD) yang memiliki fungsi dan tugas dalam memaksimalkan kinerja anggota DPRD sebagai perangkat kesatuan kerja upaya kesinambungan penyerapan aspirasi dan pelaksanaan layanan terhadap masyarakat Kabupaten Bulukumba. Oleh sebab itu untuk mengetahui bentuk kepuasan masyarakat Bulukumba sebagai umpan balik dari pelaksanaan kinerja layanan sekertariat DPRD Kabupaten Bulukumba, seyogyanya masyarakat perlu melakukan penilaian dalam memaksimalkan kinerja DPRD Kabupaten Bulukumba.

\section{KAJIAN PUSTAKA}

Sekretariat Dewan Perwakilan Rakyat Daerah (DPRD) ialah unit pelayanan untuk memenuhi kebutuhan teknis dan administratif bagi anggota DPRD (Anirwan \& Annas 2020). Sekertariat DPRD salah satu perangkat daerah untuk mendukung kelancaran dan wewenang DPRD. Sekertariat DPRD sebagai pemberian pelayanan administratif terhadap DPRD secara teknis operasional bertanggungjawab kepada pimpinan DPRD, secara administratif bertanggungjawab terhadap bupati melalui sekertaris daerah (Sekda). Sekertariat DPRD secara umum memiliki tugas berdasarkan peraturan bupati Bulukumba nomor 62 Tahun 2018 ialah membantu bupati dalam menyelenggarakan administrasi kesektariatan dan keuangan, mendukung pelaksanaan tugas dan fungsi Dewan Perwakilan Rakyat Daerah (DPRD), dan menyediakan maupun mengoordinasikan tenaga ahali yang diperlukan. Untuk menjalankan tugas dan fungsi sekertariat DPRD Kabupaten Bulukumba sebagai outcome dari kualitas kinerja maka dibantu oleh tiga kepala bagian yaitu: bagian umum dan keuangan, bagiang persidangan dan perundang-undangan, serta bagian fasilitas pengawasan dan penganggaran. Selain gambaran umum tugas sekertariat DPRD menjadi salah satu indikator keberhasilan kinerja yang maksimal, maka fungsi sekertariat DPRD sangat patut untuk diperhatikan. Berdasarkan pasal 4 peraturan bupati nomor Bulukumba 62 Tahun 2018 menjelaskan fungsi sekertariat DPRD yaitu: penyelenggaraan administarsi kesektariatan Dewan Perwakilan Rakyat Daerah, penyelenggaraan administarsi keuangan Dewan Perwakilan Rakyat Daerah, fasilitas penyelenggaraan rapat-rapat Dewan Perwakilan Rakyat Daerah, penyediaan dan pengkoordinasian tenaga ahli yang diperlukan oleh Dewan Perwakilan Rakyat Daerah, pembinaan, pengkoordinasian, pengendalian, dan pengawasan tugas kepala bagian, serta pelaksanaan fungsi lain dengan kewenangan dan bidang tugasnya.

Pelayanan publik berdasarkan undang-undang nomor 25 Tahun 2009, ialah kegiatan atau rangkaian kegiatan dalam rangka pemenuhan kebutuhan bagi setiap warga negara dan penduduk atas barang, jasa, dan/atau pelayanan administratif yang disediakan oleh seluruh 
penyelenggara pelayanan. Selain itu layanan publik (Public Service) adalah segala kegiatan layanan yang dilakukan oleh penyelenggara layanan publik sebagai upaya memenuhi kebutuhan penerima pelayanan maupun pelaksana layanan (Ratminto, \& Winarsih. 2013). Sedangkan kualitas layanan ialah penyesuain terhadap perincian-perincian (Conformance To Specification) dimana kualitas ini dipandang sebagai derajat keunggulan yang ingin dicapai, dilakukan kontrol terus menerus dalam mencapai keunggulan tersebut upaya untuk memenuhi kebutuhan jasa secara bersama (Dachdy, Echdar, \& Maryadi, 2021). Olehnya itu pelayanan sebagai respon terhadap kebutusan manajerial dari keseluruhan komponen untuk memenuhi nilai produk yang diinginkan maupun kualitas jasa yang diberikan. Berdasarkan undangundang nomor 25 Tahun 2009 terkait pelayanan publik maka dapat dikelompokkan menjadi 3 jenis pelayanan yaitu:

a. Pelayanan barang publik, meliputi. (a) Pengadaan $\mathrm{dm}$ penyaluran barang publik yang dilakukan oleh instansi pemerintah yang sebagian atau seluruh dananya bersumber dari anggaran pendapatan dan belanja negara dan/atau anggaran pendapatan dan belanja daerah. (b) Pengadaan dan penyaluran barang publik yang dilakukan olleh suatu badan usaha yang modal pendiriannya sebagian atau seluruhnya bersumber dari kekayaan negara dan/atau kekayaan daerah yang dipisahkan. (c) Pengadaan dan penyaluran barang publik yang pembiayaannya tidak bersumber dari anggaran pendapatan dan belanja negara atau anggaran pendapatan dan belanja daerah atau badan usaha yang modal pendiriannya sebagian atau seluruhnya bersumber dari kekayaan negara dan/ atau kekayaan daerah yang dipisahkan, tetapi keterscdiaannya menjadi misi negara yang ditetapkan dalam peraturan perundangundangan.

b. Pelayanan jasa publik, meliputi. (1) Penyediaan jasa publik oleh instansi pemerintah yang sebagian atau seluruh dananya bersumber dari anggaran pendapatan dan belanja negara dan/ atau anggaran pendapatan dan belanja daerah. (2) Penyediaan jasa publik oleh suatu badan usaha yang modal pendiriannya sebagian atau seluruhnya bersumber dari kekayaan negara dan/atau kekayaan daerah yang dipisahkan. (3) Penyediaan jasa publik yang pembiayaannya tidak bersumber dari anggaran pendapatan dan belanja negara atau anggaran pendapatan dan belanja daerah atau badan usaha yang modal pendiriannya sebagian atau seluruhnya bersumber dari kekayaan negara dan/ atau kekayaan daerah yang dipisahkan, tetapi ketersediaannya menjadi misi negara yang ditetapkan ddam peraturan perundangundangan.

c. Pelayanan administratif, meliputi. (1) Tindakan administratif pemerintah yang diwajibkan oleh negara dan diatur dalam peraturan perundang-undangan dalam rangka mewujudkan perlindungan pribadi, keluarga, kehormatan, martabat, dan harta benda warga negara. (1) Tindakan administratif oleh instansi nonpemerintah yang diwajibkan oleh negara dan diatur dalam peraturan perundang-undangan serta diterapkan berdasarkan perjanjian dengan penerima pelayanan.

Mengukur kinerja layanan sekretariat DPRD Kabupaten Bulukumba. Penilaian terkait tingkat kepuasan masyarakat mengenai konteks kinerja layanan publik sekertariat DPRD berdasarkan peraturan Menteri Aparatur Negara nomor no 14 tahun 2017 meliputi 9 unsur penilaian kinerja layanan yaitu: (1) Persyaratan, yaitu syarat yang harus dipenuhi dalam pengurusan suatu jenis pelayanan, baik persyaratan teknis maupun administratif, (2) Prosedur, yaitu tata cara pelayanan yang dibakukan bagi pemberi dan penerima pelayanan, termasuk pengaduan, (3) Waktu pelayanan, yaitu jangka waktu yang diperlukan untuk menyelesaikan seluruh proses pelayanan dari setiap jenis pelayanan, (4) Biaya/tarif, yaitu Ongkos yang dikenakan kepada penerima layanan dalam mengurus dan/atau memperoleh pelayanan dari penyelenggara yang besarnya ditetapkan berdasarkan kesepakatan antara penyelenggara dan masyarakat, (5) Produk spesifikasi jenis pelayanan, yaitu hasil pelayanan yang diberikan dan diterima sesuai dengan ketentuan yang telah ditetapkan. Produk pelayanan ini merupakan hasil dari setiap spesifikasi jenis pelayanan, (6) Kompetensi pelaksana, yaitu kemampuan yang harus dimiliki oleh pelaksana meliputi pengetahuan, keahlian, keterampilan, dan pengalaman, (7) Perilaku pelaksana, yaitu sikap petugas dalam memberikan pelayanan, (8) Penanganan 
pengaduan, saran dan masukan, adalah tata cara pelaksanaan penanganan pengaduan dan tindak lanjut. (9) Sarana dan Prasarana, dimana Sarana adalah segala sesuatu yang dapat dipakai sebagai alat dalam mencapai maksud dan tujuan. Prasarana adalah segala sesuatu yang merupakan penunjang utama terselenggaranya suatu proses (usaha, pembangunan, proyek). Sarana digunakan untuk benda yang bergerak (komputer, mesin) dan prasarana untuk benda yang tidak bergerak (gedung).

Kinerja (Performance) ialah sebagai tingkat prestasi dan produktivitas maupun keberhasilan seseorang, kelompok, maupun organisasi dalam proses periode tertentu (Manansal, 2014). Prespektif lain terkait kinerja adalah tingkat capaian suatu kegiatan atau perencanaan dalam mewujudkan gagasan atau sasaran, dari suatu tujuan, misi dan visi dalam organisasi maupun institusi yang tertuang dalam perencanaan organisasi (Syukur, 2019). Secara sederhan bahwa kinerja pelayanan sebagai prestasi dari hasil kemampuan individu maupun organisasi dalam memberikan pelayanan terhadap konstituen. Untuk mengukur kinerja layanan Sekretariat DPRD Kabupaten Bulukumba (Dwiyanto, 2006) memaparkan beberapa indikator yang dapat digunakan yaitu: (1) Produktivitas, Sikap mental yang selalu berusaha dan mempunyai pandangan bahwa mutu kehidupan hari ini harus lebih baik dari kemarin, dan hari esok akan lebih baik darihari ini, (2) Kualitas layanan, Cenderung menjadi penting dalam menjelaskan kinerja organisasi, (3) Responsivitas, Kemampuan birokrasi untuk mengenali kebutuhan masyarakat, menyusun agenda dan prioritas, (4) Responsibilitas, Menjelaskan apakah pelaksanaan kegiatan birokrasi public itu dilakukan sesuai dengan prinsip-prinsip administrasi yang benar dengan kebijakan birokrasi, baik yang eksplisit maupun implisit, (5) Akuntabilitas, Menunjukan pada seberapa besar kebijakan dan kegiatan birokrasi publik tunduk pada para pejabat publik yang dipilih oleh rakyat.

\section{METODE PENELITIAN}

Penelitian ini dilaksanakan di Kabupaten Bulukumba dengan rens waktu Januari sampai dengan Februari 2021, dengan mengukur kinerja layanan sekretariat DPRD Kabupaten Bulukumba, pendekatan penelitian yaitu metode kuantitatif dengan pengukuran menggunakan skala likert, Teknik non-probability sampling yang dimana tidak memberikan peluang/kesempatan terhadap semua unsur anggota populasi, penentuan sampel dilakukan secara purposive sampling dengan teknik penentuan sampel berdasarkan pertimbangan tertentu. Jumlah sampel pada penelitian ini sebanyak 30 responden yaitu Anggota DPRD Kabupaten Bulukumba periode 2019-2024. Pengumpulan data primer dilakukan dengan cara wawancara secara terstruktur mempertanyakan pertanyaan kuesioner, pengumpulan data sekunder dilakukan dengan penelitian kepustakaan (Library Research). Analisis data dengan skala likert yaitu skala psikometrik digunakan dalam wawancara dengan panduan kuesioner untuk mengukur sikap, pendapat, dan persepsi responden (Sugiyono, 2012).

\section{HASIL PENELITIAN DAN PEMBAHASAN}

\subsection{Hasil Penelitian}

Pada penelitian ini responden yang memberikan penilaian terhadap kinerja sekertariat Dewan Perwakilan Rakyat Daerah (DPRD) sebanyak 30 responden, yang menjadi responden adalah anggota Dewan Perwakilan Rakyat Daerah (DPRD) Kabupaten Bulukumba periode tahun 2019-2024. 


\section{Laki-Laki $\quad$ Perempuan}

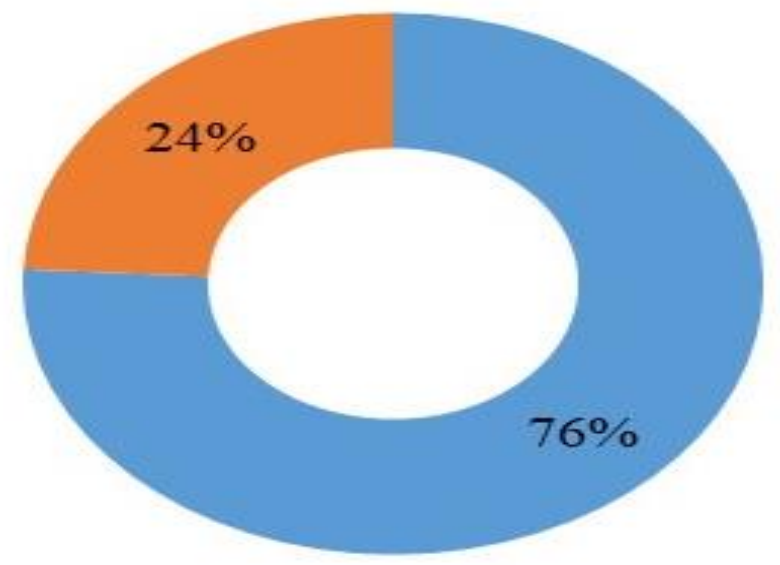

Gambar 1. Grafik Responden Berdasarkan Jenis Kelamin

Pada gambar 1, mengenai karakteristik responden, berdasarkan jenis kelamin menunjukkan bahwa responden laki-laki lebih banyak yaitu $76 \%$ dibandingkan dengan responden perempuan yaitu $24 \%$

- Usia

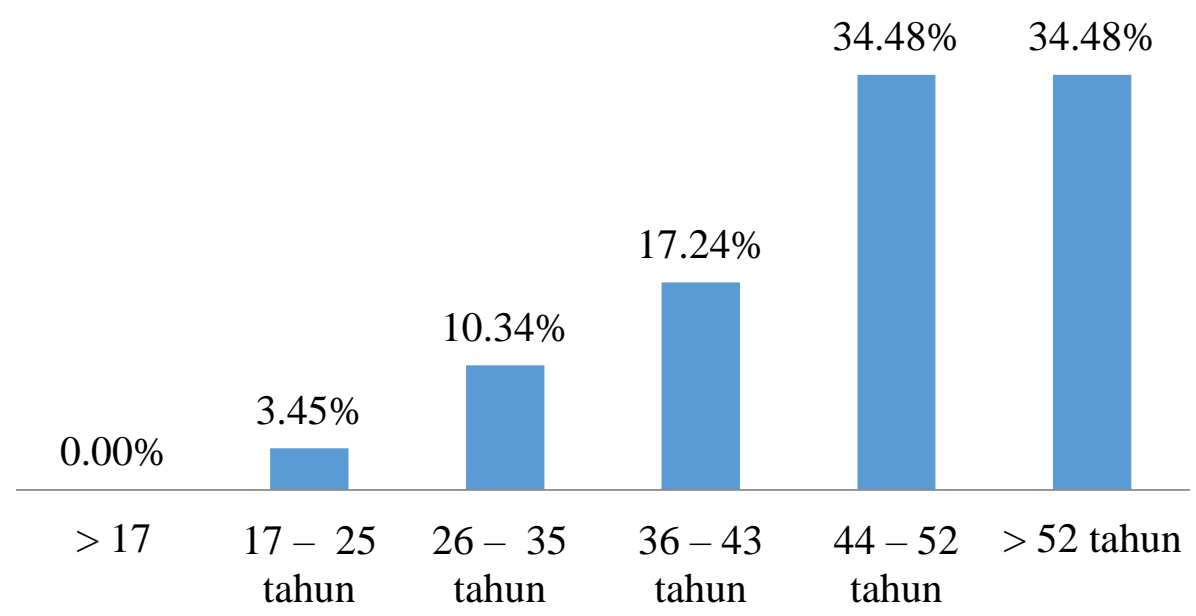

Gambar 2. Grafik Responden Berdasarkan Usia

Pada gambar 2, menjelaskan bahwa responden berdasarkan kategori usia secara berurut dari yang terbesar sampai yang terkecil ialah usia 44-52 dan $\geq 52$ tahun masingmsing sebesar 34,48\% responden. Usia 36-43 tahun sebesar 17,24\% responden, usia $26-35$ tahun sebesar $10,34 \%$ responden, usia $17-25$ tahun sebesar $3,45 \%$ responden, usia $\leq 17$ tahun sebesar $0,00 \%$ responden.

Tabel 1. Penilaian Kinerja Layanan Sekretariat DPRD Kabupaten Bulukumba.

\begin{tabular}{|c|c|c|c|}
\hline No. & Unsur Pelayanan & $\begin{array}{c}\text { Nilai } \\
\text { Unsur } \\
\text { Pelayanan }\end{array}$ & $\begin{array}{c}\text { NRR } \\
\text { tertimbang }\end{array}$ \\
\hline 1 & Persyaratan & 2,928 & 0,325 \\
\hline 2 & Sistem, Mekanisme, dan Prosedur & 2,917 & 0,324 \\
\hline 3 & Waktu Penyelesaian & 2,859 & 0,318 \\
\hline 4 & Biaya/Tarif & 2,953 & 0,328 \\
\hline 5 & Produk Spesifikasi jenis pelayanan & 2,950 & 0,328 \\
\hline 6 & Kompetensi pelaksana & 2,948 & 0,328 \\
\hline
\end{tabular}




\begin{tabular}{|c|c|c|c|}
7 & Perilaku Pelaksana & 3,058 & 0,340 \\
\hline 8 & Penanganan, pengaduan, saran dan masukan & 2,910 & 0,323 \\
\hline 9 & Sarana dan Prasarana & 2,979 & 0,331 \\
\hline \multicolumn{2}{|c|}{ Total Nilai Rata-Rata (NRR) } & $\mathbf{2 , 9 4 5}$ \\
\hline IKM & $\mathbf{7 3 , 6 2}$ \\
\hline \multicolumn{2}{|c|}{ Mutu Pelayanan } & Kurang Baik \\
\hline Kinerja Unit Layanan
\end{tabular}

Sumber: Data Primer Diolah 2021

Pada tabel 1, menunjukkan bahwa kinerja layanan sekretariat DPRD Kabupaten Bulukumba yaitu 73,62 dengan mutu layanan ' $C$ ' dan kinerja unit layanan sekretariat 'Kurang Baik'. Sedangkan dari 9 unsur kinerja layanan tersebut pada umumnya mendapatkan mutu layanan ' $\mathrm{C}$ ' dan kinerja unit layanan 'Kurang Baik' dengan nilai unsur tertinggi terdapat pada unsur ke-7 perilaku pelaksana yaitu 3,058 dengan nutu layanan ' $\mathrm{C}$ ' dan kinerja unit layanan 'Kurang Baik' dan nilai unsur terendah terdapat pada unsur ke-3 waktu penyelesaian yaitu 2,859 dengan mutu layanan ' $C$ ' dan kinerja unit layanan 'Kurang Baik'.

Tabel 2. Penilaian Kinerja Layanan Bagian Umum dan Keuangan, Sekretariat DPRD Kabupaten Bulukumba.

\begin{tabular}{|c|c|c|c|}
\hline No. & Unsur Pelayanan & $\begin{array}{l}\text { Nilai Unsur } \\
\text { Pelayanan }\end{array}$ & $\begin{array}{c}\text { NRR } \\
\text { tertimbang }\end{array}$ \\
\hline 1 & Persyaratan & 2,940 & 0,327 \\
\hline 2 & Sistem, Mekanisme, dan Prosedur & 2,871 & 0,319 \\
\hline 3 & Waktu Penyelesaian & 2,750 & 0,306 \\
\hline 4 & Biaya/Tarif & 2,957 & 0,329 \\
\hline 5 & Produk Spesifikasi jenis pelayanan & 2,931 & 0,326 \\
\hline 6 & Kompetensi pelaksana & 2,931 & 0,326 \\
\hline 7 & Perilaku Pelaksana & 3,095 & 0,344 \\
\hline 8 & Penanganan, pengaduan, saran dan masukan & 2,871 & 0,319 \\
\hline 9 & Sarana dan Prasarana & 2,983 & 0,331 \\
\hline \multicolumn{3}{|c|}{ Total Nilai Rata-Rata (NRR) } & 2,925 \\
\hline \multicolumn{3}{|r|}{ IKM } & 73,13 \\
\hline \multicolumn{3}{|r|}{ Mutu Pelayanan } & $\mathbf{C}$ \\
\hline \multicolumn{3}{|c|}{ Kinerja Unit Layanan } & Kurang Baik \\
\hline
\end{tabular}

Sumber: Data Primer Diolah 2021

Pada tabel 2, menunjukkan bahwa kinerja layanan bagian umum dan keuangan, sekretariat DPRD Kabupaten Bulukumba yaitu 73,13 dengan mutu layanan ' $C$ ' dan kinerja unit layanan 'Kurang Baik'. Sedangkan dari 9 unsur kinerja layanan tersebut terdapat 1 unsur layanan mendapatkan mutu layanan 'B' dan kinerja unit layanan 'Baik', 8 unsur layanan lainnya mendapat mutu layanan ' $\mathrm{C}$ ' dan kinerja unit layanan 'Kurang Baik'. Nilai unsur tertinggi terdapat pada unsur ke-7 perilaku pelaksana yaitu 3,095 dengan mutu layanan 'B' dan kinerja unit layanan 'Baik' dan Dan unsur layanan nilai terendah ialah unsur ke-3 Waktu Penyelesaian yaitu 2,750 dengan mutu pelayanan "C" dan kinerja unit pelayanan "Kurang Baik". 
Tabel 3. Penilaian Kinerja Layanan Bagian Persidangan dan Perundang-Undangan, Sekretariat DPRD Kabupaten Bulukumba.

\begin{tabular}{|c|c|c|c|}
\hline No. & Unsur Pelayanan & $\begin{array}{l}\text { Nilai Unsur } \\
\text { Pelayanan }\end{array}$ & $\begin{array}{c}\text { NRR } \\
\text { tertimbang }\end{array}$ \\
\hline 1 & Persyaratan & 2,948 & 0,328 \\
\hline 2 & Sistem, Mekanisme, dan Prosedur & 2,983 & 0,331 \\
\hline 3 & Waktu Penyelesaian & 2,966 & 0,330 \\
\hline 4 & Biaya/Tarif & 2,948 & 0,328 \\
\hline 5 & Produk Spesifikasi jenis pelayanan & 2,966 & 0,330 \\
\hline 6 & Kompetensi pelaksana & 2,983 & 0,331 \\
\hline 7 & Perilaku Pelaksana & 3,034 & 0,337 \\
\hline 8 & Penanganan, pengaduan, saran dan masukan & 2,940 & 0,327 \\
\hline 9 & Sarana dan Prasarana & 3,000 & 0,333 \\
\hline \multicolumn{3}{|c|}{ Total Nilai Rata-Rata (NRR) } & 2,974 \\
\hline \multicolumn{3}{|r|}{ IKM } & 74,35 \\
\hline \multicolumn{3}{|c|}{ Mutu Pelayanan } & $\mathbf{C}$ \\
\hline \multicolumn{3}{|c|}{ Kinerja Unit Layanan } & Kurang Baik \\
\hline
\end{tabular}

Sumber: Data Primer Diolah 2021

Pada tabel 3, menunjukkan bahwa kinerja layanan bagian persidangan dan perundang undangan, sekretariat DPRD Kabupaten Bulukumba yaitu 74,35 dengan nilai mutu layanan ' $C$ ' dan kinerja unit layanan 'Kurang Baik'. Sedangkan dari 9 unsur layanan pada umumnya mendapatkan mutu layanan ' $C$ ' dan kinerja unit layanan 'Kurang Baik'. Nilai unsur tertinggi terdapat pada unsur ke-7 perilaku pelaksana yaitu 3,034 dan mutu layanan ' $C$ ' kinerja unit layanan 'Kurang Baik', sedangkan nilai unsur terendah unsur ke-8 penanganan, pengaduan, saran, dan masukan yaitu 2,940 dengan mutu layanan ' $C$ ' kinerja unit layanan 'Kurang Baik'.

Tabel 4. Penilaian Kinerja Layanan Bagian Fasilitas Penganggaran dan Pengawasan, Sekretariat DPRD Kabupaten Bulukumba.

\begin{tabular}{|c|l|c|c|}
\hline No. & \multicolumn{1}{|c|}{ Unsur Pelayanan } & $\begin{array}{c}\text { Nilai Unsur } \\
\text { Pelayanan }\end{array}$ & $\begin{array}{c}\text { NRR } \\
\text { tertimbang }\end{array}$ \\
\hline 1 & Persyaratan & 2,897 & 0,322 \\
\hline 2 & Sistem, Mekanisme, dan Prosedur & 2,897 & 0,322 \\
\hline 3 & Waktu Penyelesaian & 2,862 & 0,318 \\
\hline 4 & Biaya/Tarif & 2,954 & 0,328 \\
\hline 5 & Produk Spesifikasi jenis pelayanan & 2,954 & 0,328 \\
\hline 6 & Kompetensi pelaksana & 2,931 & 0,326 \\
\hline 7 & Perilaku Pelaksana & 3,046 & 0,338 \\
\hline 8 & Penanganan, pengaduan, saran dan masukan & 2,920 & 0,324 \\
\hline 9 & Sarana dan Prasarana & 2,954 & 0,328 \\
\hline \multicolumn{2}{|r|}{ Total Nilai Rata-Rata (NRR) } & $\mathbf{2 , 9 3 5}$ \\
\hline \multicolumn{2}{|r|}{ IKM } & $\mathbf{7 3 , 3 7}$ \\
\hline \multicolumn{2}{|r|}{} \\
\hline
\end{tabular}




\begin{tabular}{|c|c|c|c|}
\hline No. & Unsur Pelayanan & $\begin{array}{c}\text { Nilai Unsur } \\
\text { Pelayanan }\end{array}$ & $\begin{array}{c}\text { NRR } \\
\text { tertimbang }\end{array}$ \\
\hline & Kinerja Unit Layanan & Kurang Baik \\
\hline
\end{tabular}

Sumber: Data Primer Diolah 2021

Pada tabel 4, menunjukkan bahwa kinerja layanan bagian fasilitas penganggaran dan pengawasan, sekretariat DPRD Kabupaten Bulukumba yaitu 73,37 dengan nilai mutu layanan ' $C$ ' dan kinerja unit layanan 'Kurang Baik'. Sedangkan dari 9 unsur pada umumnya juga mendapatkan mutu layanan ' $C$ ' dan kinerja unit layanan 'Kurang Baik'. Nilai unsur tertinggi terdapat pada unsur ke-7 perilaku pelaksana yaitu 3,046 dengan mutu layanan ' $\mathrm{C}$ ' dan unit kinerja layanan 'Kurang Baik' dan nilai unsur terendah ialah unsur ke-3 waktu penyelesaian yaitu 2,862 dengan mutu layanan ' $\mathrm{C}$ ' dan kinerja unit layanan 'Kurang Baik'

\subsection{Pembahasan}

Sebagaimana penyajian data diatas mengenai kinerja layanan secara umum Sekertariat DPRD Kabupaten Bulukumba dari 3 bagian layanan yaitu: bagian umum dan keuangan, bagian persidangan dan perundang-undangan, dan bagian fasilitas penganggaran dan pengawasan. Kinerja layanan masih kategori kurang baik dengan nilai IKM 73,62. Rendahnya penilaian anggota DPRD Bulukumba mengenai kinerja layanan dari 3 bagian dapat dilihat dari, belum adanya unsur yang terealisasi secara maksimal atau keseluruhan unsur mendapat kategori penilaian kurang baik, sehingga mempengaruhi penilaian kinerja layanan secara umum. Untuk meningkatkan kinerja layanan sekertariat DPRD Bulukumba dalam penelitian (Annas, \& Anirwan, 2019) dalam menjalankan tugas dan fungsinya sebagai pelayan Anggota DPRD hal yang paling mendasar perlu diperhatikan bagian sekretariat adalah kualitas Sumber Daya Manusia, Masalah SDM perlu diperhatikan dengan cara membekali pengembangan kapasitas dan ilmu pengetahuan pelaksana layanan sekertariat guna memahami orientasi dan komponen kerja disetiap bagian layanan masingmasing.

Berdasarkan hasil penelitian mengenai kinerja layanan bagian umum dan keuangan sekertariat DPRD, anggota DPRD Bulukumba sebagai responden menilai bahwa bagian layanan tersebut kinerjanya masih kategori kurang baik dengan nilai IKM 73,13. Rendanhya penilaian anggota DPRD disebabkan karena 8 unsur masih berkategori kurang baik meskipun ada satu unsur yang kategori baik, akan tetapi tidak memberikan siknifikansi nilai secara maksimal, diketahui bahwa umumnya tugas dan fungsi layanan bagian umum dan keuangan sekretariat DPRD yaitu: merencanakan anggaran kegiatan anggota DPRD, memproses pencairan anggaran anggota DPRD meliputi (gaji, tunjangan, SPPD, dll), pemenuhan kegiatan rutin anggota DPRD, dan pemenuhan kebutuhan pelayanan tamu anggota DPRD. Sebagaimana dalam penelitian (Muhajir, dkk. 2021). Penilaian antara ke-9 unsur ini saling berkaitan untuk menentukan skala kategori, olehnya itu jika penilaian berkategori rendah dalam pemberian layanan maka perlu pemahaman tugas dan fungsi disetiap bagian layanan, sehingga pengguna layanan tersebut merasa maksimal dilayani dan pemberi layanan memahami betul proses proses dan tahapan prosedur dalam memberikan layanan.

Sebagaimana data hasil penelitian mengenai kinerja layanan bagian persidangan dan perundang-undangan sekertariat DPRD. Responden menilai bahwa kinerja unit layanan bagian persidangan dan perundang-undangan masih kategori kurang baik dengan nilai IKM 74,35. Anggota DPRD Bulukumba sebagai responden menganggap bahwa kinerja bagian layanan dari 9 unsur layanan keseluruhan memberikan penilaian kurang baik sehingga mempengaruhi penilaian umum kualitas layanan. Layanan bagian persidangan dan perundang-undangan secara umum memiliki tugas dan fungsi yaitu: melaksanakan rapat-rapat internal anggota DPRD, pelaksanaan rapat-rapat anggota DPRD dengan pemerintah daerah, pelaksanaan orientasi dan pendalaman tugas meliputi (Bimtek, 
Sosialisasi, dan Diklat), dan pelaksanaan kunjungan kerja/studi banding keluar daerah. Upaya meningkatkan kinerja layanan sangat perlu dilakukan, Menurut Bernhard Sutor (Sukmawati, M. 2016) dalam menjalankan tugas dan memaksimalkan kinerja layanan sekertariat DPRD perlu dibekali dimensi modalitas dan dimensi tindakan terkhusus bagian layanan persidangn dan perundang-undangan, olehnya itu sekertariat DPRD sebagai bagian dari instansi DPRD perlu memiliki komitmen dan keinginan dalam menjalankan fungsi dan tugasnya.

Berdasarkan hasil penelitian mengenai kinerja layanan bagian fasilitas penganggaran dan pengawasan sekretariat DPRD Kabupaten Bulukumba. kinerja layanan masih kategori kurang baik berdasarkan penilian responden dengan nilai IKM 73,37. Disebabkan karena ke-9 unsur unit layanan yang dinilai juga masih kategori kurang baik, sehingga sangat mempengaruhi nilai IKM. Bagian layanan fasilitas penganggaran dan pengawasan sekretariat DPRD diketahui bahwa tugas dan fungsi sebagai indikator penilaian yaitu: pemenuhan kebutuhan penerimaan aspirasi masyarakat, pemenuhan kebutuhan pelaksanaan reses, dan pemenuhan kebutuhan sosialisasi dan pelaksanaan pengawasan peraturan daerah. Untuk meningkatkan penilaian terhadap kinerja layanan menjadi baik, bagian layanan sekertariat DPRD perlu bersikap responsiveness yaitu kesungghan pegawai dalam menyelesaikan tugas, sikap tanggap pelayan terhadap anggota DPRD serta kemampuan pihak pelayan menjawab pertanyaan dan menjelaskan permasalahan yang didapatkan oleh pengguna layanan (Sutanti, N. 2014).

Ketiga bagian layanan yang diukur diatas menjelaskan bahwa kinerja layanan di sekertariat DPRD Kabupaten Bulukumba menunjukkan secara umum masih kurang baik. Anggota DPRD Kabupaten Bulukumba periode 2019-2024 sebagai penerima layanan masih belum puas dengan kinerja disetiap bagian unit layanan, data diatas disajikan pula dengan jelas beberapa catatan perbaikan disetiap indikator dan variabel bagian layanan yang diukur pada penelitian ini.

\section{KESIMPULAN}

Berdasarkan hasil pembahasan sebelumnya diatas, mengenai pengukuran kinerja layanan sekertariat DPRD Kabupaten Bulukumba dalam mendukung kinerja DPRD Kabupaten Bulukumba periode 2019-2024, maka dapat disimpulkan:

a. Berdasarkan penilaian anggota DPRD Kabupaten Bulukumba periode 2019-2021 secara umum layanan sekertariat DPRD Kabupaten Bulukumba mendapatkan kinerja 'kurang baik' dengan mutu layanan ' $\mathrm{C}$ '.

b. Pada bagian umum dan keuangan Sekertariat DPRD Kabupaten Bulukumba mendapatkan kinerja 'kurang baik' dengan mutu layanan ' $C$ '. Sedangkan 8 unsur unit layanan mendapat kinerja 'kurang baik' dan 1 unsur mendapat penilaian kinerja 'baik'.

c. Pada bagian persidangan dan perundang-undangan Sekertariat DPRD Kabupaten Bulukumba mendapatkan kinerja 'kurang baik' dengan mutu layanan 'C'. Sedangkan ke 9 unsur unit layanan mendapatkan penilaian 'kurang baik'.

d. Pada bagian fasilitas, penganggaran, dan pengawasan Sekertariat DPRD Kabupaten Bulukumba mendapatkan kinerja 'kurang baik' dengan mutu layanan 'C'. Sedangkan ke 9 unsur unit layanan mendapatkan penilaian 'kurang baik'.

\section{UCAPAN TERIMAKASIH}

Peneliti sangat berterimakasih terhadap 30 anggota DPRD Kabupaten Bulukumba periode 2019-2024 yang telah memberikan waktu, persepsi, pandangan, dan kesempatan selama melaksanakan penelitian. Serta Badan Kesatuan Bangsa dan Politik Kabupaten Bulukumba yang kiranya dengan sabar melayani penerbitan persuratan administrasi penelitian. 


\section{DAFTAR PUSTAKA}

Anirwan, A., \& Annas, A. (2020). Upaya Peningkatan Kinerja Layanan Sekretariat DPRD Kabupaten Soppeng. Journal of Governance and Local Politics (JGLP), 2(2), 131-150.

Annas, A., \& Anirwan, A. (2019). Upaya Peningkatan Kinerja DPRD Kabupaten Soppeng. Journal of Governance and Local Politics (JGLP), 1(2), 82-99.

Dachdy, D., Echdar, S., \& Maryadi, M. (2021). Pengaruh Kemampuan Individu, Motivasi Dan Etos Kerja Terhadap Kualitas Pelayanan Aparatur Sipil Negara Pada Sekretariat DPRD Kabupaten Pinrang. Jurnal Magister Manajemen Nobel Indonesia, 2(3), 429-438.

Dwiyanto, A. (2006). Penilaian Kinerja Organisasi Publik, Makalah Dalam Seminar Sehari: Kinerja Organisasi Sektor Publik, Kebijakan dan Penerapannya. Fisipol UGM, Yogyakarta.

Edyanto, and Karsiman. (2018). "Leadership Bupati Dalam Pembangunan Di Kabupaten Tambrauw (Studi Kepemimpinan Bupati Tambrauw).” Sosio e-kons 10(2): 143.

Manansal, B. F. (2014). Kinerja pegawai di sekertariat DPRD kota bitung. Jurnal politico, 3(1).

Muhajir, H., Tamrin, S. H., Sirnan, S., Salam, E. F. R., \& Annas, A. (2021). Pelayanan Bantuan Sosial Di Tengah Pandemi Covid-19 Kabupaten Soppeng. Jurnal Ilmiah Tata Sejuta STIA Mataram, 7(2), 283-295.

Peraturan Bupati Bulukumba Nomor 62 Tahun (2018) Tentang Perubahan Kedua Atas Peraturan Bupati Bulukumba Nomor 72 Tahun 2016 Tentang Kedudukan, Tugas dan Fungsi, Susunan Organisasi, dan Tata Kerja Kesektariat Daerah Kabupaten Bulukumba.

Peraturan Daerah Kabupaten Bulukumba Nomor 6 Tahun (2014) Tentang Perubahan Atas

Peraturan Daerah Nomor 9 Tahun 2008 Tentang Organisasi dan Tata Kerja Sekretariat Daerah dan Sekretariat Dewan Perwakilan Rakyat Daerah Kabupaten Bulukumba.

Peraturan Menteri Pemberdayaan Aparatur Negara Nomor 14 Tahun (2017) Tentang Pedoman Survei Kepuasan Masyarakat Terhadap Penyelenggaraan Pelayanan Publik

Peraturan Pemerintah Republik Indonesia Nomor 18 Tahun (2016) Tentang Organisasi Perangkat Daerah

Ratminto, dan Winarsih. (2013). Manajemen Pelayanan. Pustaka Pelajar, Yogyakarta.

Sugiyono. (2012). Metode Penelitia Kombinasi (Mix Methode). Bandung, Alfabeta.

Sukmawati, M. (2016). Etika Birokrasi Pada Bagian Perundang-Undangan Di Sekretariat Dewan Perwakilan Rakyat Daerah Kabupaten Sigi. Katalogis, 4(7).

Sutanti, N. (2014). Strategi Peningkatan Kualitas Layanan Di Sekretariat DPRD Kabupaten Magelang Tahun 2012. Jurnal Riset Manajemen Sekolah Tinggi Ilmu Ekonomi Widya Wiwaha Program Magister Manajemen, 1(1), 1-21.

Syukur, A. (2019). Pengaruh Kepemimpinan, Komunikasi Organisasi dan Budaya Organisasi Terhadap Kinerja Pegawai Sekretariat Dprd Kabupaten Tegal. Magisma: Jurnal Ilmiah Ekonomi dan Bisnis, 7(2), 90-99.

Undang-Undang Nomor 23 Tahun (2014) Tentang Pemerintahan Daerah.

Undang-Undang Nomor 25 Tahun (2009) Tentang Pelayanan Publik.

Undang-Undang Republik Indonesia Nomor 17 Tahun (2014) Tentang Majelis Permusyawaratan Rakyat, Dewan Perwakilan Rakyat, Dewan Perwakilan Daerah, Dan Dewan Perwakilan Rakyat Daerah (MD3). 